\title{
KEMANDIRIAN DALAM PEMBELAJARAN MATEMATIKA DI MADRASAH TSANAWIYAH
}

\author{
Sutama $^{1)}$, Sri Hartini ${ }^{2)}$, dan Meggy Novitasari ${ }^{3)}$ \\ ${ }^{1) \& 3)}$ Universitas Muhammadiyah Surakarta \\ ${ }^{2)}$ MTs Negeri I Wonogiri \\ sutama@ums.ac.id \\ Email: Sriharti7306@gmail.com
}

\begin{abstract}
The purpose of this research is to describe the independence in MTs mathematics learning. This research method using qualitative method by using holistic research design. Techniques of data collection using observation, interviews, and documentation. This research uses interactive analysis model. The results of this study are: Self-reliance planning in learning mathematics prepared by the head of the madrasah with the board of teachers at the time of meeting the division of tasks, preparation of activities and budget annual or RKAT with attention to the condition of students and the surrounding environment. Implementation of independence in learning mathematics in MTs by integrating it into the structure and content of the curriculum, student program. The integration of learning independence in mathematics learning is seen in the activities of opening and closing the lesson by reading prayer with the meaning that led by the class leader.
\end{abstract}

Keywords: independence, learning, mathematics

\begin{abstract}
Abstrak. Tujuan penelitian ini adalah untuk mendeskripsikan kemandirian dalam pembelajaran matematika MTs. Metode penelitian ini menggunakan metode kualitatif dengan menggunakan desain penelitian holistik. Teknik pengumpulan data menggunakan observasi, wawancara, dan dokumentasi. Penelitian ini menggunakan model analisis interaktif. Hasil penelitian ini adalah: Perencanaan kemandirian dalam pembelajaran matematika disusun oleh kepala madrasah bersama dewan guru pada waktu rapat pembagian tugas, penyusunan rencana kegiatan dan anggaran tahunan atau RKAT dengan memperhatikan kondisi siswa dan lingkungan sekitarnya. Pelaksanaan kemandirian dalam pembelajaran matematika di MTs dengan mengintegrasikannya pada struktur dan muatan kurikulum, program kesiswaan. Pengintegrasian kemandirian belajar dalam pembelajaran matematika terlihat dalam kegiatan membuka dan menutup pelajaran dengan membaca doa dengan artinya yang dipimpin ketua kelas.
\end{abstract}

Kata kunci: kemandirian, matematika, pembelajaran

\section{Pendahuluan}

Peningkatan mutu pendidikan adalah salah satu usaha untuk tercapainya keberhasilan pendidikan suatu bangsa. Guna memperoleh output yang berkualitas pada proses pendidikan tergantung oleh berhasil tidaknya kegiatan belajar. Oleh karena itu pendidikan kita harus ditingkatkan supaya bisa menghasilkan lulusan yang dapat bersaing dengan Negara lain. Permasalahan tersebut dibutuhkan karena akan menjadi penunjang utama pembangunan nasional yang mandiri dan berkeadilan dan juga menjadi jalan keluar bagi bangsa Indonesia untuk terlepas dari kemiskinan dan pengangguran. Untuk usaha pengembangan ilmu pengetahuan 
dan teknologi tersebut dibutuhkan adanya penguasaan matematika. Di Indonesia matematika sebagai mata pelajaran yang diajarkan untuk setiap jenjang mulai dari sekolah dasar (SD) sampai perguruan tinggi.

Melalui pelajaran matematika, orang mampu mengetahui urutan penalaran dan kaidah-kaidah yang dipunyai pada pelajaran matematika, begitu juga mampu membangun model dari gejala keilmuan yang sudah diamati. Untuk mencapai itu diperlukan kemandirian diri siswa karena kemandirian siswa adalah faktor penting dalam mencapai hasil belajar yang baik. Kemandirian siswa dalam belajar perlu dikembangkan tumbuh dalam diri siswa, dengan memliki kemandirian diri siswa mengakibatkan siswa bisa menyelesaikan permasalahannya sendiri sesuai dengan kemampuan yang dimilikinya. Telah terbukti orang-orang yang mampu bertahan dikerasnya kehidupan adalah mereka yang terbiasa mandiri, Tamrin $(2008: 49)$

Kemandirian dalam pembelajaran merupakan hal yang penting, karena kemandirian menuntut siswa bertanggung jawab atas keberhasilan belajarnya sendiri. Peneliti masih melihat ada masalah yang berhubungan dengan kemandirian belajar, masih ada guru dalam pembelajaran kurang bervariasi, kurang menyenangkan sehingga siswa merasa jenuh dan bosan, masalah dari siswa tidak percaya diri sehingga masih ada sebagian siswa yang bergantung pada temannya ketika ada tugas dari guru. Kemandirian belajar pada pelajaran matematika memberikan keluasan pada siswa dalam memahami atau mencari sumber belajar, siswa diberikan kesempatan dalam mencari materi melalui media internet. Pada pembelajaran matematika siswa diberimotivasi agar menguasi kompetensi sesuai yang diharapkan supaya tercapai tujuan pembelajaran. Berdasarkan observasi yang peneliti laksanakan di Madrasah Madrasah Tsanawiyah (MTs), masih terdapat kemandirian siswa yang belum berkembang secara optimal. Siswa itu kurang mempunyai tanggung jawab, dalam belajar tidak tekun, tidak menyelesaikan tugas-tugas yang diberikan oleh guru, di dalam kelas bercerita, mengganggu temannya. Siswa tersebut belum mempunyai kemandirian belajar.

Menurut Steinberg pada Nurhayati (2016: 130), kata "mandiri" diambil dari dua istilah yang pengertiannya disejajarkan silih berganti, yaitu autonomy dan independence, karena perbedaannya sangat tipis, independence dalam arti kebebasan secara umum menunjuk pada kemampuan individu melakukan sendiri aktivitas hidup, tanpa menggantungkan bantuan orang lain, sedangkan otonomy berarti kemampuan untuk memerintah sendiri, mengurus sendiri, atau mengatur kepentingan sendiri

Menurut Johnson dan Medinus pada Nurhayati (2016: 131), kemandirian merupakan salah satu cirri kematangan yang memungkinkan anak berfungsi otonom dan berusaha kearah prestasi pribadi dan tercapainya suatu tujuan. Kartadinata pada Nurhayati (2016: 132), mengemukakan bahwa kemandirian sebagai kekuatan motivasional dalam diri individu untuk mengambil keputusan dan menerima tanggung jawab atau konsekuensi. Menurut Mu'tadin pada Nurhayati (2016: 132), bahwa kemandirian mengandung makna: (a) suatu keadaan di mana seseorang memiliki hasrat bersaing untuk maju demi kebaikan dirinya, (b) mampu mengambil keputusan dan inisiatif untuk mengatasi masalah yang dihadapi, (c) memiliki kepercayaan diri dalam mengerjakan tugas-tugas, dan bertanggung jawab terhadap apa yang dilakukannya.

Pendapat-pendapat ahli diatas dalam kemandirian dapat disimpulkan bahwa kemandirian mengindikasikan adanya unsure-unsur: tanggung jawab, percaya diri, berinisiatif, memiliki motivasi yang kuat untuk maju demi kebaikan dirinya, mantap mengambil keputusan sendiri, berani menanggung risiko dari keputusannya, mampu menyelesaikan masalah sendiri, tidak menggantungkan diri kepada orang lain, memiliki hasrat berkompetisi, mampu mengatasi hambatan, melakukan sesuatu 
dengan tepat, gigih dalam usaha, melakukan sendiri segala sesuatu tanpa bantuan orang lain, bebas bertindak, tidak terpengaruh lingkungan, mampu mengatur kebutuhan sendiri, tegas bertindak, dan menguasai tugastugas.

Kemandirian secara psikososial tersusun dari tiga aspek pokok yaitu: (1) mandiri emosi adalah aspek kemandirian yang berhubungan dengan perubahan kedekatan atau keterikaitan hubungan emosional individu, terutama sekali dengan orang tua atau orang dewasa lainnya yang banyak melakukan interaksi dengannya, (2) mandiri bertindak adalah kemampuan untuk membuat keputusan secara bebas dan menindaklanjutinya, (3) mandiri berpikir adalah kebebasan untuk memaknai seperangkat prinsip benar-salah, baik-buruk, apa yang berguna dan sis-sis bagi dirinya, Stenberg pada Nurhayati (2016 : 133).

Ciri mandiri dalam emosi dapat dilihat dalam hal: (1) menahan diri untuk meminta bantuan orang lain saat mengalami kegagalan, kesedihan, kekecewaan, kekhawatiran, (2) memandang orang lain lebih obyektif dengan segala kekurangan dan kelebihan, (3) memandang orang tua dan guru sebagai orang pada umumnya, bukan semata-mata sebagai orang yang sempurna, (4) memiliki energy emosi hebat untuk melepaskan diri dari ketergantungan kepada orang lain. Ciri kepribadian mandiri dalam bertindak ditandai oleh: (1) kemampuan untuk membuat keputusan sendiri dan mengetahui dengan pasti kapan seharusnya meminta pertimbangan orang lain, (2) mampu mempertimbangkan berbagai alternative dari tindakannya berdasarkan penilaian sendiri, mengetahui kapan dan bagaimana harus bersikap terhadap pengaruh, tawaran, bantuan, nasehat, dan dapat menangkap maksud-maksud yang terkandung dibalik tawaran, ajakan, pengaruh, bantuan, saran, pendapat yang disampaikan orang lain, (3) membuat keputusan yang bebas bagaimana harus bertindak melaksanakan keputusan yang bebas bagaiman harus bertindak melaksanakan keputusan dengan penuh percaya diri, Hill, Holmbeck pada Nurhayati (2016: 135).
Ciri kepribadian mandiri dalam berpikir ditandai: (1) cara berpikir semakin abstrak, (2) keyakinan-keyakinan yang dimiliki semakin berbasis idiologis, (3) keyakinankeyakinan semakin mendasarkan pada nilainilai mereka sendiri bukan hanya nilai yang ditanamkan oleh orang tua/ figure, Steinberg pada Nurhayati (2016 : 136)

Kemandirian belajar bukan berarti sebagai belajar mandiri atau belajar sendiri. Kemandirian belajar adalah bentuk belajar yang memberikan otonomi dan tanggung jawab kepada pembelajar untuk berinisiatif dan berperan aktif dalam mengatur sendiri berbagai aspek kegiatan belajar sesuai dengan kebutuhan dan kemampuannya, tanpa selalu tergantung kepada orang lain. Kemandirian belajar mengacu kepada kemampuan siswa, dengan atau tanpa bantuan orang lain yang relevan, dan kemampuan menentukan saat kapan dibutuhkan bantuan dan kapan tidak membutuhkan bantuan dari orang lain dalam belajar, Kesten pada Nurhayati (2016 : 140).

Puncak belajar mandiri adalah terjadinya kegiatan belajar oleh peserta. Peserta mampu belajar di tempat yang ditentukan sendiri, pada waktu yang dipilihnya sendiri, dan dengan cara belajar sendiri tanpa bimbingan tatap muka dari orang lain, Majid (2013 : 105). Proses belajar mandiri memberikan kesempatan pada peserta didik untuk mencerna materi ajar dengan sedikit bantuan guru. Mereka mengikuti kegiatan pembelajaran dengan materi ajar yang sudah dirancang khusus, sehingga masalah atau kesulitan sudah diantisipasi sebelumnya. Dari proses belajar mandiri tersebut, diperoleh peran guru atau instruktur diubah menjadi fasilitator atau perancang proses belajar. Sebagai fasilitator, seorang guru atau instruktur membantu peserta didik mengatasi kesulitan belajar, atau dapat menjadi mitra belajar untuk materi tertentu pada program tutorial.

Menurut Kozma, belle dan William pada Nurhayati (2016 : 141), kemandirian belajar merupakan bentuk belajar yang memberikan kesempatan kepada pembelajar untuk menentukan tujuan, sumber dan 
kegiatan belajar sesuai dengan kebutuhan sendiri. Dalam proses belajar, pembelajar dapat berpatisipasi secara aktif menentukan apa yang akan dipelajari dan bagaimana cara mempelajarinya. Menurut Miarso pada Nurhayati (2016 : 141), kemandirian belajar adalah pengaturan program belajar yang diorganisasikan sedemikian rupa sehingga setiap pembelajar dapat memilih atau menentukan bahan dan kemajuan belajarnya sendiri.

Permasalahan diatas menjadi tanggung jawab seorang guru bagaimana usaha yang dilakukan untuk menumbuhkan kemandirian siswa. Dengan cara guru memberikan motivasi dan menyusun perencanaan pembelajaran yang didalamnya memuat kemandirian.

Tujuan penelitian ini untuk mendeskripsikan kemandirian dalam pembelajaran matematika Madrasah Tsanawiyah (MTs). Mandiri berarti keadaan dapat berdiri sendiri dan tidak bergantung pada orang lain yang membuat tumbuh menjadi pribadi yang sanggup mengatasi segala persoalan sendiri, bukan berarti tidak ada peran orang lain dalam menyelesaikan dan juga bukan berarti menyingkirkan faktor luar sama sekali, tetapi menjadi mandiri peran orang lain hanya sebagian kecil saja.

\section{Metode Penelitian}

Metode penelitian ini menggunakan metode kualitatif dengan desain penelitian etnografi. Tempat penelitian adalah di Madrasah Tsanawiyah (MTs) Negeri 1 Wonpgiri. Penelitian dilakukan mulai bulan Maret 2018 sampai bulan Agustus 2018.

Data diperoleh dari nara sumber atau informan yaitu Kepala Madrasah, Wakil kepala Madrasah Bidang Kesiswaan, Wakil Kepala Madrasah Bidang Humas, Guru Matematika dan siswa.

Teknik analisis data ini menggunakan analisis model interaktif. Miles dan Huberman dalam Sugiyono (2013 : 337), "Aktivitas dalam analisis data kualitatif dilakukan secara interaktif dan berlangsung secara terus menerus sampai tuntas.

\section{Hasil dan Pembahasan}

Kemandirian belajar ini bertujuan untuk menciptakan anak berfikir kreatif, hal ini seperti yang dikemukakan oleh Umit Kopzhassarova, Gulden Akbayeva, Zhanar Eskazin, Gulbarshyn Belgibayeva dan Akerke Tazhikeyeva (2016), yang berjudul "Enhancement of Stdebts'Independent Learning Through Their Critical Thinking Skilis Development" bahwa kemandirian belajar yang tepat memberikan kontribusi yang besar terhadap pemikiran kritis siswa, keterampilan reflektif. Penyelenggaraan kemandirian belajar yang tepat memberikan kontribusi yang besar terhadap pembangunan pemikiran kritis siswa, keterampilan reflektif.

Kemandirian dalam pembelajaran matematika penyusunannya bersama membuat program-program madrasah, diawal semester bisa juga awal tahun ajaran dengan menetapkan nilai-nilai yang akan dicapai. Dalam penyusunan ini terdiri dari semua komponen madrasah dan terintegrasi dengan mata pelajaran matematika. Perencanaan kemandirian belajar harus memperhatikan juga bagaimana pengelolaan kelas, media yang dipilih sehingga menghasilkan hasil yang optimal, ini sesuai dengan hasil penelitian dari Sutama (2012) yang berjudul "Pengelolaan Pembelajaran Matematika Pasca Bencana Erupsi Merapi" bahwa pengelolaan kelas dan media yang dilakukan dengan tepat membuat pembelajaran matematika efektif, produktif, dan menumbuhkan motivasi untuk pemahaman konsep. Pengelolaan bahan pembelajaran secara holistik menghasilkan hasil yang optimal dan berfikir reflektif bagi siswa. Pengelolaan interaksi membuat proses pembelajaran hidup dan menyenangkan dan akhirnya menghasilkan pencapaian tujuan pembelajaran.

Madrasah Tsanawiyah (MTs) berusaha menggabungkan pelaksanaan kemandirian belajar dengan budaya madrasah yang bersifat demokratis, struktural, polisional. Permasalahan pertama kemandirian bersifat struktural artinya pelaksanaan kemandirian terintegrasi pada tata tertib dan peraturan 
madrasah. Pelaksanaan kemandirian belajar merupakan tanggung jawab semua warga madrasah. Guru, pegawai dan semua warga madrasah ini diharuskan menjadi teladan atau panutan siswa. Permasalahan kedua, kemandirian belajar bersifat polisional artinya madrasah mengintegrasikan pelaksanaan kemandirian belajar dengan tetap berdasarkan kebijakan kurikulum (tercantum di dokumen kurikulum 2013), penerimaan peserta didik baru, serta etika dalam bergaul yaitu pembiasaan member salam kepada setiap bertemu dengan masyarakat madrasah ini baik kepada yang lebih tua ataupun terhadap sesama. Siswa mempunyai ruang dan waktu yang cukup dalam mengembangkan kemandirian belajar dengan cara latihan dan pembiasaan. Permasalahan yang ke tiga, bersifat demokratis, wujud demokratis ini pada saat ada kegiatan luar kelas sebagai alat untuk pengembangan kemandirian siswa seperti pemilihan fungsionaris OSIS. Permasalahn ke empat, pelaksanaan pengembangan kemandirian belajar dengan bimbingan konseling (BK), dan mengikuti kegiatan ekstrakurikuler yang ada di Madrasah Tsanawiyah (MTs).

Pedoman yang dipakai dalam pelaksanaan kemandirian belajar adalah dokumen kurikulum 2013. Penerapan kemandirian belajar pada kurikulum ini adalah penting, seperti disebutkan dalam penelitian Rachel Field, James Duffi (2013), bahwa mengajar siswa secara eksplisit keterampilan belajar mandiri adalah hal yang penting, dengan strategi berbasis kurikulum yang akan memberikan kontribusi pada tugas yang signifikan dalam pengamatan. Madrasah Tsanawiyah (MTs) melaksanakan kurikulum 2013 adalah mengintegrasikan pendidikan kemandirian sebagaimana disebutkan pada perencanaan kemandirian belajar. Pelaksanaan kemandirian belajar terintegrasi di program dan kurikulum yang sudah dibuat oleh kepala madrasah dan dewan guru ketika rapat awal tahun pelajaran.
Sarana madrasah dalam melaksanakan kemandirian belajar adalah apel pagi dan upacara bendera. Kepala madrasah dan dewan guru bertugas sebagai Pembina yang diatur dengan jadwal yang telah tersusun. Dalam pembinaan selalu menyampaikan nilai-nilai yang sudah ditetapkan. Dengan melalui upacara bendera kemandirian siswa tercipta dengan sendirinya. Setiap hari pelaksanaan upacara bendera siswa diwajibkan datang lebih awal. Inilah yang menjadi tantangan bagi siswa supaya siswa berlatih mandiri untuk mengkondisikan dirinya. Seperti supaya datang lebih awal siswa akan bangun lebih awal dari biasanya, persiapan makan pagi, mempersiapkan segala peralatan yang di butuhkan untuk dibawa ke madrasah. Di Madrasah Tsanawiyah (MTs) saat upacara ada yang bertugas biasanya guru BK dan dibantu OSIS , mereka berdiri pintu gerbang untuk mencatat dan mengatur barisan bagi siswa yang terlambat. Semua siswa yang terlambat dicatat di buku pembinaan selanjut akan diproses wali kelas.

Pelaksanaan kemandirian belajar tergabung dalam mata pelajaran matematika terlihat dari kegiatan awal pelajaran salah satu siswa atau di madrasah ini ketua kelas memimpin berdoa dan di akhir pelajaran juga dipimpin berdoa oleh ketua kelas. Kegiatan ini sudah rutin tanpa disuruh oleh guru siswa sudah melaksanakan dengan rutin. Pelaksanaan kemandirian belajar dalam pembelajaran matematika berjalan pada proses pembelajaran. Pelaksanaan kemandirian belajar oleh guru dengan pengamatan langsung di kelas. Dalam pelaksanaan ini indikatornya yaitu siswa bisa mengerjakan tugas tidak bergantung siswa lain. Hasil temuan ini diperkuat oleh hasil penelitian Wiwat Orawiwatnakul, Saovapa Wichadee, (2017), bahwa pembelajaran mandiri rata-rata meningkatkan kepercayaan diri yang tinggi. Semakin tinggi tingkat kemandirian siswa maka semakin tinggi prestasi belajarnya. Semua ini disebabkan anak sudah mulai memiliki kepercayaan pada 
kemampuan dirinya sendiri dengan sadar, disiplin, berupaya benar-benar untuk meraih prestasi belajar, sehingga tidak mempunyai rasa rendah diri, selalu bisa menyelesaikan masalah yang dihadapi.

Pelaksanaan kemandirian belajar dilakukan juga dengan media internet dalam mencari materi yang disesuaikan tema saat pembelajaran. Pelaksanaan ujian nasional tahun pelajaran 2017/2018 berbasis komputer. Ini sangat mendukung dalam pengembangan kemandirian belajar, bertanggung jawab dan percaya diri tidak mencari jawaban dari teman atau orang lain. Hasil penelitian Islam, M. N., (2011) mengemukakan bahwa pembelajaran mandiri bahasa inggris melalui internet memfasilitasi peningkatan tingkat bahasa inggris. Dengan pembelajaran mandiri melalui internet sangat menguntungkan dan meningkatkan kemandirian belajar.

Hasil penelitian MS.Kavita Nagpal, MS.Priyamakhija, DR.Leena James, Prof Gyanprakash (2013), mengemukakan bahwa saya tidak bisa mengajari siapapun, saya hanya bisa membuat mereka berpikir, pembelajaran mendesak siswa untuk bertanggung jawab atas pembelajaran mereka dan bukan menjadi kapal kosong, pembelajaran mandiri mengkonfirmasi pentingnya panda dari format ceramah menuju gaya yang lebih interaktif, pembelajaran mandiri manfaat bagi pengusaha dalam mendorong siswa mengembangkan keterampilan yang relevan.

Bahri, (2008 : 39). Kemandirian adalah "hasrat untuk mengerjakan segala sesuatu bagi diri sendiri". Artinya kemandirian adalah suatu keadaan dimana seseorang yang memiliki hasrat bersaing untuk maju demi kebaikan dirinya dihadapi, memiliki kepercayaan diri dalam mengerjakan tugastugasnya, bertanggung jawab terhadap apa yang dilakukannya. Dengan demikian kualitas input siswa sebagai faktor pendukung terwujudnya kemandirian belajar siswa di madrasah ini. Preoritas dalam seleksi penerimaan peserta didik baru adalah kualitas akademik dan kualitas kepribadian.
Peran orang tua menjadi faktor pendukung yang kedua, kemandirian dapat terus di ketahui perkembangannya dengan adanya peran orang tua. Orang tua bisa memantau dan membina kekurangan anak dan permasalahan yang dihadapinya. Kedisplinan anak merupakan faktor pendukung juga untuk menilainya menggunakan pedoman tata tertib madrasah, dalam memantau perilaku dan sikap siswa. Dengan penilaian terhadap kemandirian belajar siswa yang dilakukan oleh kepala madrasah dengan dewan guru dan pegawai, selama ini masih ada faktor penghambat diantaranya adalah kurangnya komitmen sebagian guru dan pegawai untuk sebagai contoh yang baik, peran serta orang tua yang minim, kurangnya sarana prasarana yang mendorong terwujudnya kemandirian.

\section{Penutup}

Perencanaan kemandirian belajar dalam pembelajaran matematika Madrasah Tsanawiyah (MTs), pertama diawali penyusunan perangkat pembelajaran, dokumen kurikulum 2013 sebagai pedoman dalam membuat RPP. Kedua perencanaan kemandirian belajar membuat programprogram madrasah, pada awal semester atau awal tahun ajaran dengan menetapkan nilainilai yang akan dicapai. Dalam penyusunan ini terdiri dari semua komponen madrasah dan terintegrasi dengan mata pelajaran matematika.

Pelaksanaan kemandirian belajar bersifat demokratis, struktural, polisional. Bersifat demokratis, wujud demokratis ini pada saat ada kegiatan luar kelas sebagai alat untuk pengembangan kemandirian siswa seperti pemilihan fungsionaris OSIS, pelaksanaan pengembangan kemandirian belajar dengan bimbingan konseling (BK), dan mengikuti kegiatan ekstrakurikuler yang ada di Madrasah Tsanawiyah (MTs). Bersifat struktural artinya pelaksanaan kemandirian terintegrasi pada tata tertib dan peraturan madrasah. Bersifat polisional artinya madrasah mengintegrasikan pelaksanaan kemandirian belajar dengan tetap berdasarkan kebijakan kurikulum. 
Berbagai ucapan terima kasih kami Ucapan terima kasih kami sampaikan kepada sampaikan kepada berbagai pihak yang Direktur Sekolah Pascasarjana dan Ketua telah mendukung kegiatan penelitian ini. Lembaga Penelitian UMS beserta stafnya, Ucapan terima kasih kami sampaikan kepada yang telah memberikan fasilitas dan dorongan Direktorat Riset dan Pengabdian Masyarakat sehingga kami bisa melakukan penelitian. Direktorat Jenderal penguatan Riset dan Ucapan terima kasih juga kami sampaikan Pengembangan Kementerian Riset, Teknologi, kepada kepala Dinas Pendidikan, kepala dan dan Pendidikan Tinggi yang telah membantu guru matematika MTs Negeri 1 Wonogiri, dalam pendanaan biaya penelitian multi tahun yang telah membantu proses penelitian melalui Hibah Penelitian Tim Pascasarjana. sehingga berjalan sesuai perencanaan.

\section{Daftar Pustaka}

Author, A. (2013). Independent learning and student development, 2(2),

27-35.

Budiyanto, M. dan Machali, I. (2014). "Pembentukan Karakter Mandiri Melalui Pendidikan Agriculture di Pondok Pesantren Islamic Studies Center Aswaja Lintang Songo Piyungan Bantul Yogyakarta". Jurnal Pendidikan Karakter, Tahun IV, Nomor 2, Juni 2014.

Buku KPK Modul Pendidikan Anti Korupsi SMP-MTs Kelas 8 - Backup Data www.dadangjsn. blogspot.com.pdf. (n.d.).

Cunska, A., \& Savicka, I. (2012). Use of ICT teaching-learning methods make school math blossom. Procedia Social and Behavioral Sciences, 69(Iceepsy), 1481-1488. https://doi. org/10.1016/j.sbspro.2012.12.089

Dahar, R.W., (2011). Teori-Teori Belajar \& Pembelajaran. Bandung:PT Gelora Aksara Pratama

Fatinah, S., Haji, Z., Shahrill, M., \& Mundia, L. (2015). Factors Contributing to Effective Mathematics Teaching in Secondary Schools in Brunei Darussalam. Procedia - Social and Behavioral Sciences, 186, 474-481. https://doi.org/10.1016/j.sbspro.2015.04.169

Fitriana, I., Ihsan, H., Annas, S., (2015). “ Pengaruh Efikasi Diri, Aktivitas, kemandirian Belajar Dan Kemampuan Berpikir Logis Terhadap Hasil Belajar Matematika Pada Siswa Kelas VIII SMP”. Journal of EST,Volume 1, Nomor 2: 86-10, September 2015

Halimah, L., (2017). Keterampilan Mengajar. Bandung:PT Rafika Aditama

Hidayah, I. (2015). Model of Independent Working Group of Teacher and Its Effectiveness towards the Elementary School Teacher's Ability in Conducting Mathematics Learning, 214(June), 43-50. https://doi.org/10.1016/j.sbspro.2015.11.591

Ismaya, B., (2015). Pengelolaan Pendidikan. Bandung: PT Rafika Aditama

Kopzhassarova, U., Akbayeva, G., \& Eskazinova, Z. (2016). Enhancement of Students ' Independent Learning Through Their Critical Thinking Skills Development, 11(18).

Kurniasih, I., (2017). Sukses Mengajar: Panduan Lengkap menjadi Guru Kreatif dan Inovatif. Jakarta:Pustaka Diantara

Majid, A., (2013). Strategi Pembelajaran. Bandung:PT Remaja Rosdakarya

Mulyono, D. (2017). The influence of learning model and learning independence on mathematics learning outcomes by controlling students $\hat{a} €^{\mathrm{TM}}$ early ability, 12(7), 689-708.

Nugroho, A.W., (2018), “ Pengelolaan Pendidikan Karakter Kemandirian Belajar Pada 
Pembelajaran IPS Di SMP Negeri 1 Tawangsari”. Tesis. Surakarta: Sekolah Pasca Sarjana Nurhayati, (2016). Psikologi Pendidikan Inovatif. Yogyakarta:Pustaka Pelajar

Permendikbud Nomor 21 Tahun 2016 tentang Standar Isi Pendidikan Dasar dan Menengah Permendikbud Nomor 22 Tahun 2016 tentang Standar Proses Pendidikan Dasar dan Menengah Risnawati, (2016). Psikologi Pembelajaran Matematika. Yogyakarta:Aswaja Pressindo

Suastika, K. (2017). Mathematics Learning Model of Open Problem Solving to Develop Students ' Creativity, 12(6), 569-577.

Sumardjoko, B., (2015). Metode Penelitian Kualitatif. Surakarta:Diperbanyak oleh UMS

Sutama, (2012). "Pengelolaan Pembelajaran Matematika Pasca Bencana Erupsi Merapi”, Laporan Penelitian. Surakarta: Sekolah Pasca Sarjana UMS.

Sutama, (2012a). Metode Penelitian Pendidikan: Kuantitatif, Kualitatif, PTK, $R \& D$. Kartasura:Fairuz Media

Sutama, (2017b). Pedoman Penulisan Tesis. Surakarta:Diperbanyak oleh UMS

Suwanto, D. (2012). “ Pengaruh Kemandirian Siswa, Motivasi belajar, Dan Pendapatan Orang Tua Terhadap Prestasi belajar Ilmu Pengetahuan Sosial Siswa kelas XI SMA Negeri 3 Bantul Semester II Tahun Pelajaran 2011/2012". Tesis. Yogyakarta: Sekolah Pasca Sarjana PGRI.

Undang-Undang Republik Indonesia Nomor 20 Tahun 2003 teantang Sistem Pendidikan Nasional

Uno, H.,B., (2016). Perencanaan Pembelajaran. Jakarta:Bumi Aksara

Warsono, Hariyanto, (2013). Pembelajaran Aktif. Bandung:PT Remaja Rosdakarya

Wena, M., (2016). Strategi Pembelajaran Inovatif Kontemporer. Jakarta: PT Bumi Aksara 